\title{
MYCOLOGICAL EXAMINATION OF FISH FEED STUFF WITH SPECIAL REFERENCE TO MYCOTOXIN PRODUCTION
}

\author{
Maha M.Kholife ${ }^{1,2 *}$, Amgad A.Moawad ${ }^{2}$, Amany M.Diab ${ }^{3}$, El-keredy M.S. Abeer ${ }^{4}$
}

${ }^{1}$ Department of Bacteriology, Mycology and Immunology, Animal Health Research Institute, Kafr El Sheikh, Egypt, ${ }^{2}$ Department of Bacteriology, Mycology and Immunology, Faculty of Veterinary Medicine, Kafrelsheikh University, Egypt, ${ }^{3}$ Aquatic Microbiology, Faculty of Aquatic and Fisheries sciences, Kafrelsheikh University. ${ }^{4}$ Department of Biochemistry, Nutritional deficiency diseases and Toxicology, Animal Health Research Institute, Kafr El Sheikh, Egypt

${ }^{*}$ Corresponding author, E-mail: maha.mahmod1988@gmail.com

\begin{abstract}
Mycotoxin contamination is considered as one of the most economic problems for livestock and feed industries. A total of thirty fish feedstuffs were collected for isolation and identification of fungi from fish farms in Kafr El Sheikh Governorate, Egypt. Five fungal genera were isolated from all examined feedstuffs. The most frequent isolated fungi was Aspergillus spp. (86.66\%) followed by Penicillium spp. (23.33\%), and Fusariam spp. (10\%), Mucor spp. (6.66\%) then Rhizopus spp. (3.33\%). Aspergillus niger was the most prevailing genus (43.33\%) followed by Aspergillus flavus ((30\%), and Aspergillus fumigatus (6.66\%), Aspergillus versicolor (3.33\%) then Aspergillus terrus (3.33\%). Aspergillus ochraceus was not found despite the presence of ochratoxin A (OTA) in low concentrations. Some mycotoxins were produced by more than one fungal species. Mycotoxins determination using HPLC revealed that $23.33 \%$ (7/30) of examined fish feed samples were positive, while 23 samples $(76.66 \%)$ were mycotoxins free. In positive samples of mycotoxins, aflatoxins (AF) and OTA represented $23.33 \%, 10 \%$, respectively. The estimated carcinogenic aflatoxins were $\mathrm{AFB}_{1}, \mathrm{AFB}_{2}, \mathrm{AFG}_{1}$ with a percentage of $23.33 \%$, $13.34 \%, 6.67 \%$, respectively, but $A F G_{2}$ was not found. About $42.86 \%$ of the AFs producing fish feeds was higher than the permissible limit of aflatoxins (permissible limit is 20 $\mathrm{ppb}$ ). The aflatoxigenic ability of the recovered nine A. flavus referred to 6 out of 9 $(66.67 \%)$ were aflatoxin producers. Polymerase chain reaction (PCR) was carried out using the norsolonic acid reductase (nor), versicolorin $\mathrm{A}$ (ver-1) and O-methylsterigmatocystin (omtA) as aflatoxin producing genes of the isolated $A$. flavus strains. From the AF producing $A$. flavus, $50 \%$ was above the permissible limit. Therefore, the high contamination of fish feedstuffs with fungi, AFB 1 and low OTA in fish farms indicated potential risks to fish liveliness, derived products and the health of fish consumers.
\end{abstract}

Key words: fish feedstuff; fungi; aflatoxins; ochratoxin A

\section{Introduction}

Received: January 2019

Accepted for publication: February 2019
Fish serve as a substantial source of human dietary protein worldwide, especially in African countries (1). Fish feed is considered the 
enormous cost item in the aquaculture industry and represents $40-50 \%$ of the total production costs in intensive culture systems (2). The low quality feed intake have adverse effects on animal health and productivity (3). Presence of mold in fish feeds indicates contamination probably due to improper selection of ingredients for manufacturing or an inadequate storage. Mold increase over a temperature range of $10-40{ }^{\circ} \mathrm{C}, \mathrm{pH}$ range of $4-8$ and humidity levels greater than $62 \%$ as well as more than $12-13 \%$ moisture. Fungal growth and production of their metabolites (mycotoxins) are related to extremes weather, improper storage conditions causing low feedstuff quality and bad feeding conditions (4). The most repeatedly isolated genus of fungi in feed was Aspergillus spp. followed by penicillium spp. and Aspergillus fla$v u s$ is the most prevalent isolated fungi species (5).

Mycotoxins are a structurally diverse group of mostly small molecular weight compounds, produced by the secondary metabolism of fungi that grow in feeds, from the harvested products to the consumers. Mycotoxins occur sporadically both seasonally and geographically (6). Many reports indicated an economic losses from mycotoxicosis in fish from chronic infection as well as increasing feed conversion ratios and unforeseen outbreaks of fish mortality (7, 8 ). The remarkable mycotoxin types of concern produced by fungal genera Aspergillus, Penicillium and Fusarium include the aflatoxins, ochratoxin A, trichothecenes and fumonisins (9).

Aflatoxin was considered to have a great importance in aquaculture. Aflatoxin exerts carcinogenic effects in fish as in all animal species (10). The intake of moderate to high doses of aflatoxin by fish develop an acute intoxication, called acute aflatoxicosis, that generally leads to poor heath, fertility, productivity loss, weight gain reduction and immunosuppression (11). The main types of aflatoxins are B1, B2, $\mathrm{G} 1$, and $\mathrm{G} 2$ based on their fluorescence under UV light blue or green and relative chromatographic mobility during thin-layer chromatography (12). The main sources of $\mathrm{AFB}_{1}$ contamination in aquaculture represented in pelleted fish feed due to the isolation and identification of fungi Aspergillus spp., Penicillium spp. in feed samples, as well as other several genera (13). Ochratoxin A (OTA) is produced by Aspergillus and Penicillium species (14).

For fungal examination, the slide culture technique is carried out for some mould species identification, which characterized by their restricted growth making difficulty to be identified using the wet mount slide method (15). The prepared samples were analyzed using a validated method by reversed-phase HPLC separation and fluorescence detection after postcolumn derivatization (16).

Herein, this investigation was conducted to examine and identify the most prevalent fungi in fish feeds as well as to determine aflatoxins and OTA in examined fish feed samples moreover the aflatoxigenic ability of isolated Aspergillus flavus.

\section{Materials and methods}

Fish feed samples collection

A total of 30 fish feedstuff samples were collected from ten different fish farms in Kafr El Sheikh Governorate in Egypt. Each representative fish feedstuff sample was thoroughly ground and mixed. The samples were examined for mycotic contamination and mycotoxin production. The samples after the dilution were inoculated into plates containing prepared media for isolation Sabouraud's dextrose agar (SDA) with chloramphenicol (0.05g/1) (17). Lactophenol cotton blue stain for fungal microscopic examination prepared as previously described (18). The examined samples of fish feeds and nine isolates of A. flavus were sent to laboratory for mycotoxins determination.

\section{Isolation and purification of fungi}

The dilution of the samples was carried out (19). Approximately $10 \mathrm{~g}$ of each sample were homogenized in a sterile mortar, diluted in 90 $\mathrm{ml}$ distilled water, and then $1 \mathrm{ml}$ was transferred to tube containing $9 \mathrm{ml}$ sterile distilled water. The tube was shaken and $1 \mathrm{ml}$ was removed into a sterile petri dish containing SDA with chloramphenicol $(0.05 \mathrm{~g} / \mathrm{l})$ using surface spread method and incubated at $25-28^{\circ} \mathrm{C}$ for $7-10$ days 
under complete aseptic conditions. After incubation, the plates were examined visually and microscopically by making films. All the positive fungal cultures were purified by subculturing on SDA plates and incubated at $25-28^{\circ} \mathrm{C}$ for 3-5 days. Stock isolates maintained in SDA slopes in refrigerator for further identification.

\section{Identification of fungal isolates}

The identification of the isolated fungi recovered from the examined fish feedstuffs included the macroscopical and microscopical examination. The identification of mold genera and species was carried out $(18,20)$ for genus Aspergillus and (21-24) for the other mold genera. The macroscopical examination shed light on the rate and pattern of growth as color, texture, basal and surface mycelia. The microscopical examination of fungal colonies was carried out using both wet mount slide method and the micro slide culture technique. The slide culture method (23) was carried out in case of some mold species, which characterized by their restricted growth and failed to be detected using the wet mount slide method.

Estimation of mycotoxins in the examined fish feedstuffs

Qualitative and quantitative estimation of aflatoxins $(A F)$

Determination of aflatoxins in fish feed samples by high-performance liquid chromatography (HPLC) (16). The preparation of chemicals, standard Aflatoxin (AF) solutions of $B_{1}$, $B_{2}, G_{1}$ and $G_{2}$ were prepared (25). Extraction and clean-up procedures for HPLC analysis of the prepared samples (16) using a validated method by reversed-phase HPLC separation and fluorescence detection after post-column derivatization.

\section{Qualitative and quantitative estimation of} ochratoxin A

The samples were extracted (26) with few modifications. The sample (15 g) was blended $(15 \mathrm{~min})$ in $50 \mathrm{ml}$ of acetonitrile - water (45:05, $\mathrm{v} / \mathrm{v})$, using high speed blending and then the extract was filtered through filter paper. About 5 $\mathrm{ml}$ of the filtrate was mixed with $50 \mathrm{ml}$ of phosphate buffer saline (PBS) and filtered through a glass microfiber. Then $10 \mathrm{ml}$ of the filtrate was passed through immunoaffinity columns. OTA was eluted from the column by passing $1.5 \mathrm{ml}$ of methanol (HPLC grade) and collected in a vial. The eluate was evaporated until dryness at $40^{\circ} \mathrm{C}$ and residues were re-dissolved in $1 \mathrm{ml}$ of mobile phase i.e. acetonitrile: water: acetic acid (47/51/2, v/v/v) for HPLC analysis. Stock standard solutions of each sample were prepared then the method was validated using The European Commission (27) as for guidelines. Selectivity was determined from retention time, ion ratios, and identification-points (IP) for each analyte. The permissible limit of aflatoxins and ochratoxin A were determined as previously described (30).

Screening of aflatoxigenicity test for isolated Aspergillus flavus strains

The technique using fluorescence of agar medium under U/V light (28) was performed for detection the toxigenic strains of A. flavus including the cultivation, the observation of fluorescence and the extraction of $A$. flavus toxins. In the cultivation, the identified isolates of $A$. flavus were inoculated at the center of a solidified fluorescence agar medium in glass Petridishes then the plates were incubated at $25^{\circ} \mathrm{C}$ for 10 days. The plates were examined under U/V illumination at $360 \mathrm{~nm}$, starting from the $7^{\text {th }}$ day of incubation up to $10^{\text {th }}$ day for the detection of the fluorescence in the agar surrounding the colonies. Finally, the extraction of $A$. flavus toxins was carried out (29) whereas the toxic strains of $A$. flavus that illuminated in the fluorescence agar medium were inoculated in rice medium and incubated at $25^{\circ} \mathrm{C}$ for 15 days. At the end of incubation period, $25 \mathrm{ml}$ of chloroform were added and the mixture was thoroughly homogenized for one minute. The homogenate was centrifuged at $3000 \mathrm{rpm}$ for 10 minutes and the chloroform layer was decanted. The chloroform extraction was repeated only once. Furthermore, $1 \mathrm{ml}$ ethanol, $3 \mathrm{~g}$ copper, $111 \mathrm{~g}$ hydroxide carbonate and $5 \mathrm{~g}$ anhydrous sodium sulphate were added to the chloroform extract, mixed well and filtered. The filtrate was 
evaporated in rotatory vacuum evaporator to obtain the produced aflatoxins.

\section{Polymerase Chain Reaction (PCR) for demonstration of aflatoxigenic strains of $A$. flavus}

The demonstration of virulence factors including norsolonic acid reductase (nor), versicolorin A (ver-1) and O-methylsterigmatocystin (omtA) as aflatoxin producing genes of the isolated A. flavus strains was carried out (31) using the primers in (Table 1).

The strains of identified A. flavus were grown for 72 hours under continuous shaking conditions in the Potato Dextrose Broth (32). The mycelium was then harvested by filtration, transferred to a mortar, frozen in liquid nitrogen and ground to a powder which was resuspended in a lysis buffer $(50 \mathrm{mmol} / \mathrm{L}$ EDTA, $0.2 \% \mathrm{SDS}, \mathrm{pH}=8.5$ ) and heated immediately at $68^{\circ} \mathrm{C}$ for $15 \mathrm{~min}$. After centrifugation for 15 $\mathrm{min}$ at $15000 \mathrm{rpm}, 10 \mathrm{ml}$ volume of the supernatant fluid was transferred to a new centrifuge tube and $1 \mathrm{ml} 4 \mathrm{~mol} / \mathrm{L}$ sodium acetate was added. This solution was placed on ice for $1 \mathrm{~h}$ and centrifuged for $15 \mathrm{~min}$ at $15000 \mathrm{rpm}$. After centrifugation, the supernatant fluid was transferred to a fresh tube and extracted by genomic DNA extraction Kit.

The amplification was performed (33) on a Thermal Cycler (Master cycler, Eppendorf, Hamburg, Germany). All of the isolated A. fla$v u s$ were examined for the presence of three important aflatoxin genes (nor-1, ver-1 and omtA) enclosed in the aflatoxin biosynthesis pathway by multiplex PCR using the above mentioned 3 primer sets. PCR reaction was performed in 25 $\mu \mathrm{L}$ containing $2.5 \mu \mathrm{L} 1$ X PCR buffer, $0.75 \mu \mathrm{L}$ $50 \mathrm{mM} \mathrm{MgCl} 2,0.5 \mu \mathrm{L} 10 \mathrm{mM}$ dNTPs, $2 \mu \mathrm{L}$ of each primer, $0.2 \mu \mathrm{L}$ Taq DNA polymerase (1 $\mathrm{U} / \mu \mathrm{L}), 5 \mu \mathrm{L}$ extracted DNA as template and $8.05 \mu \mathrm{L}$ sterile distilled water. The PCR cycling protocol was applied as following: a total of 35 cycles was started with heating at $94^{\circ} \mathrm{C}$ for 5 min, and continued by denaturation for $30 \mathrm{sec}$ at $94^{\circ} \mathrm{C}$, annealing for $30 \mathrm{sec}$ at $67^{\circ} \mathrm{C}$, elongation for $30 \mathrm{sec}$ at $72^{\circ} \mathrm{C}$ and a final extension of $10 \mathrm{~min}$ at $72^{\circ} \mathrm{C}$. The amplified DNA fragments were analyzed by $1 \%$ of agarose gel electrophoresis (Applichem, Germany, $\mathrm{GmbH}$ ) in 1x TBE buffer stained with ethidium bromide and visualized on UV transilluminator. A 100 bp DNA ladder was used as a marker for PCR products.

Determination of crude protein in fish feed samples

The protein content of fish feed samples was determined (34) using the Kjeldhal method in an attempt to find a relation between the incidence of mycotoxins produced by fungi in fish feedstuffs and the crude protein (C.P) content.

\section{Results}

\section{Isolation and identification of fungi in fish feedstuff}

The mycological analysis of examined fish feedstuffs demonstrated presence of five genera of fungi. The Aspergillus species was the most predominant fungi $(86.66 \%)$, followed by Penicillium spp. (23.33\%), and Fusariam spp. (10\%), Mucor (6.66\%), and then Rhizopus (3.33\%) (Table 2). Percentages had been calculated in relation to the total number of examined samples (30 samples).

\section{Aspergillus species in fish feed samples}

Aspergillus species was the most prevalent isolated mold. Aspergillus niger was the most frequent $(43.33 \%)$, followed by $A$. flavus (30\%), and A. fumigates (6.66\%), A. versicolor $(3.33 \%)$ and then A. terrus $(3.33 \%)$ (Table 2). The results also showed that nine isolates $(30 \%)$ of Aspergillus flavus were recovered from the examined samples (Tables 2 and 3).

\section{Mycotoxins analysis}

Determination of the mycotoxins by HPLC in showed higher prevalence rate for aflatoxins in 7 samples $(23.33 \%)$ out of 30 examined samples (Table 3 ). The negative samples to mycotoxins contamination were $23(76.67 \%)$ in spite of showing fungal growth on the culture. OTA was found in three samples $(10 \%)$.

From the aflatoxins producing samples, $42.86 \%$ were higher than the permissible limit of aflatoxins in fish feeds (permissible limit is $20 \mathrm{ppb}$ ). OTA producing samples were found in 
low percentages. $66.67 \%$ of the detected OTA was higher than the permissible limit of OTA (permissible limit of OTA is $5 \mathrm{ppb}$ ). The estimated carcinogenic types of aflatoxins AFB 1 , $\mathrm{AFB}_{2}, \mathrm{AFG}_{1}$ were $(23.33 \%, 13.34 \%, 6.67 \%)$, respectively and $\mathrm{AFG}_{2}$ was not found. $\mathrm{AFB}{ }_{1}$ was the predominant type of detected aflatoxins $(23.33 \%)$ in 7 fish feed samples (Table 3). On the other hand, 3 samples (10\%) of the examined fish feedstuffs contained aflatoxins but did not give Apergillus flavus on culture (Table 3). However, 3 samples (10\%) contained OTA but did not produce Aspergillus ochraceus on culture. The negative OTA producing samples of fish feedstuff were 27 samples (90\%). OTA was $(10 \%)$ of total detected mycotoxins in the all examined fish feedstuffs but was higher than the permissible limit (5 ppb).

Crude protein determination of fish feedstuffs

The protein content in each fish feedstuff was determined (Table 3). The variations of c.p
$\%$ were recorded pointing to the difficulty to demonstrate the relation between estimated mycotoxins produced by the isolated fungi and the protein content of fish feedstuffs.

Toxigenic ability of isolated Aspergillus flavus

As shown in (Table 4), six isolates of A.flavus $(66.67 \%)$ produced aflatoxins at rate of $50 \%$ above the permissible limits while 3 isolates of A.flavus (33.33\%) were negative to aflatoxins.

The multiplex PCR of nor-1 at $400 \mathrm{bp}$, ver1 at $537 \mathrm{bp}$ and $o m t A$ at $797 \mathrm{bp}$ virulence genes was used for demonstration of aflatoxigenic strains of isolated Aspergillus flavus as shown in (Fig.1). PCR of A.flavus isolates screened that 3 isolates were negative for the aflatoxin producing genes and 6 isolates were positive. The percentages were calculated regarding to the total number of A.flavus isolated from the examined fish feedstuffs (9 isolates).

Table 1: Primers' sequences for PCR identification of aflatoxin producing genes of the isolated A. flavus strains

\begin{tabular}{|c|c|c|c|c|}
\hline Primer & $\begin{array}{l}\text { Target } \\
\text { gene }\end{array}$ & Oligonucleotide sequence $\left(5^{\prime} \rightarrow 3^{\prime}\right)$ & $\begin{array}{l}\text { Product } \\
\text { size (bp) }\end{array}$ & References \\
\hline nor-1 & & F-ACCGCTACGCCGGCACTCTCGGCAC & & \\
\hline nor-1 & aflD & R-GTTGGCCGCCAGCTTCGACACTCCG & 400 & (31) \\
\hline ver-1 & & F-GCCGCAGGCCGCGGAGAAAGTGGT & & \\
\hline ver-1 & aflM & R-GGGGATATACTCCCGCGACACAGCC & 537 & (31) \\
\hline omtA & & F-GTGGACGGACCTAGTCCGACATCAC & & \\
\hline omtA & aflP & R-GTCGGCGCCACGCACTGGGTTGGGG & 797 & (31) \\
\hline
\end{tabular}


Table 2: Incidence of isolated mold in the examined fish feedstuffs

\begin{tabular}{ccc}
\hline Fungal species & $\begin{array}{c}\text { Number of fungi in examined } \\
\text { samples }\end{array}$ & Frequency (\%) \\
\hline Aspergillus spp & 26 & $86.66 \%$ \\
Aspergillus niger & 13 & $43.33 \%$ \\
Aspergillus flavus & 9 & $30 \%$ \\
Aspergillus fumigates & 2 & $6.66 \%$ \\
Aspergillus terrus & 1 & $3.33 \%$ \\
Aspergillus versicolor & 1 & $3.33 \%$ \\
Penicillium spp & 7 & $23.33 \%$ \\
Fusarium spp & 3 & $10 \%$ \\
Mucor & 2 & $6.66 \%$ \\
Rhizopus & 1 & $3.3 \%$ \\
\hline
\end{tabular}

Percentages were calculated in relation to the total number of examined samples (30).

Table 3: Determination of aflatoxins (AF) and ochratoxin A(OTA) in fish feedstuff using (HPLC), crude protein $(\mathrm{C} . \mathrm{P} \%)$ and the isolated fungi in each examined fish feed sample

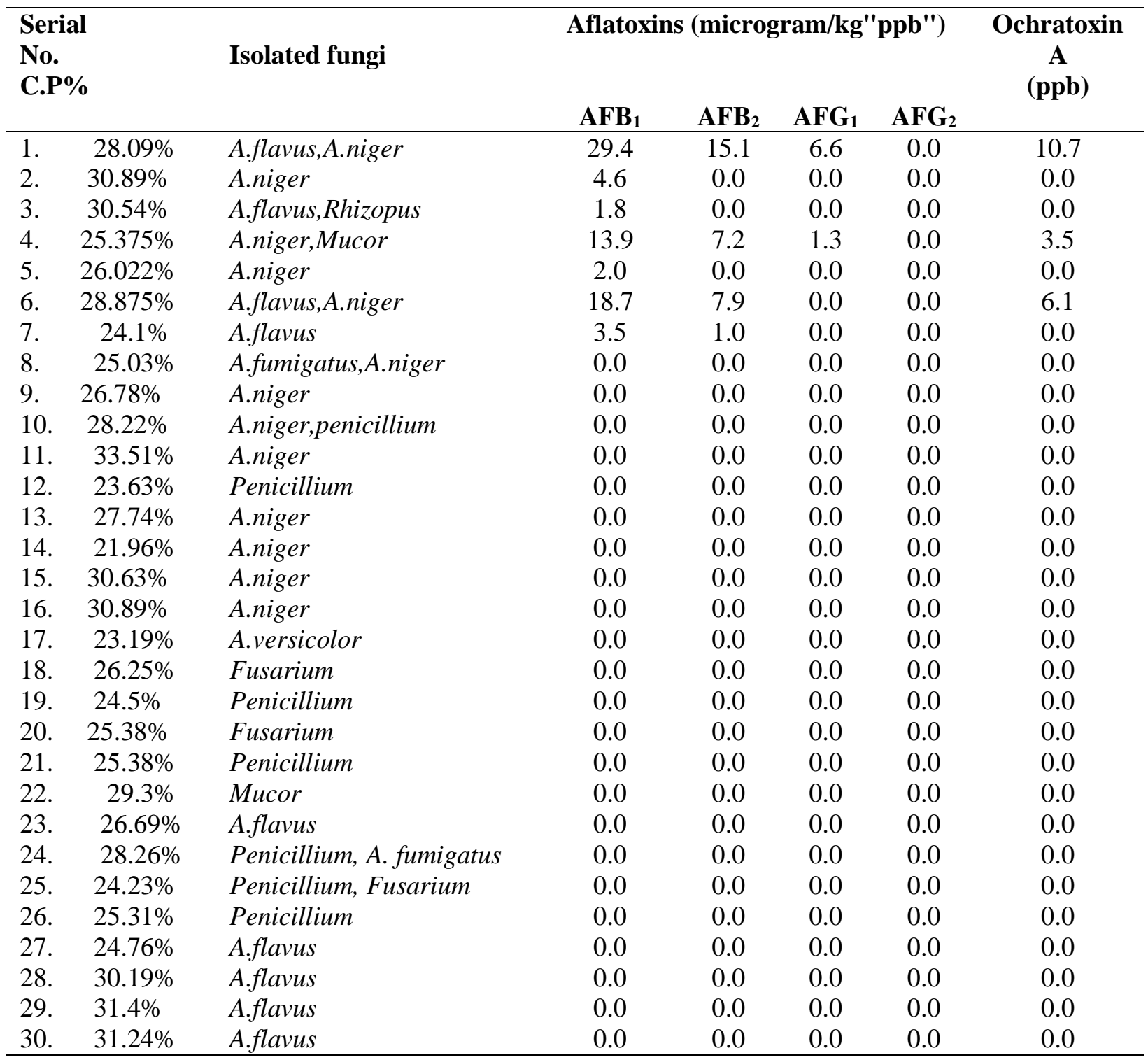


Table 4: Determination of Aflatoxins using (HPLC) produced by A.flavus isolates (microgram/K "ppb")

\begin{tabular}{cccccc} 
Serial No. & \multicolumn{2}{c}{$\begin{array}{l}\text { A. flavus iso- } \\
\text { lates }\end{array}$} & \multicolumn{5}{c}{ flavus isolates } \\
\hline 1 & -ve & $\mathrm{AFB}_{1}$ & $\mathrm{AFB}_{2}$ & $\mathrm{AFG}_{1}$ & $\mathrm{AFG}_{2}$ \\
2 & $+\mathrm{ve}$ & 0.0 & 0.0 & 0.0 & 0.0 \\
3 & $-\mathrm{ve}$ & 16.9 & 9.2 & 4.5 & 0.0 \\
4 & $+\mathrm{ve}$ & 0.0 & 0.0 & 0.0 & 0.0 \\
5 & $+\mathrm{ve}$ & 5.2 & 0.0 & 0.0 & 0.0 \\
6 & $+\mathrm{ve}$ & 14.6 & 5.7 & 0.0 & 0.0 \\
7 & $+\mathrm{ve}$ & 23.1 & 12.9 & 7.3 & 0.0 \\
8 & $-\mathrm{ve}$ & 9.4 & 0.0 & 0.0 & 0.0 \\
9 & $+\mathrm{ve}$ & 0.0 & 0.0 & 0.0 & 0.0 \\
\hline
\end{tabular}

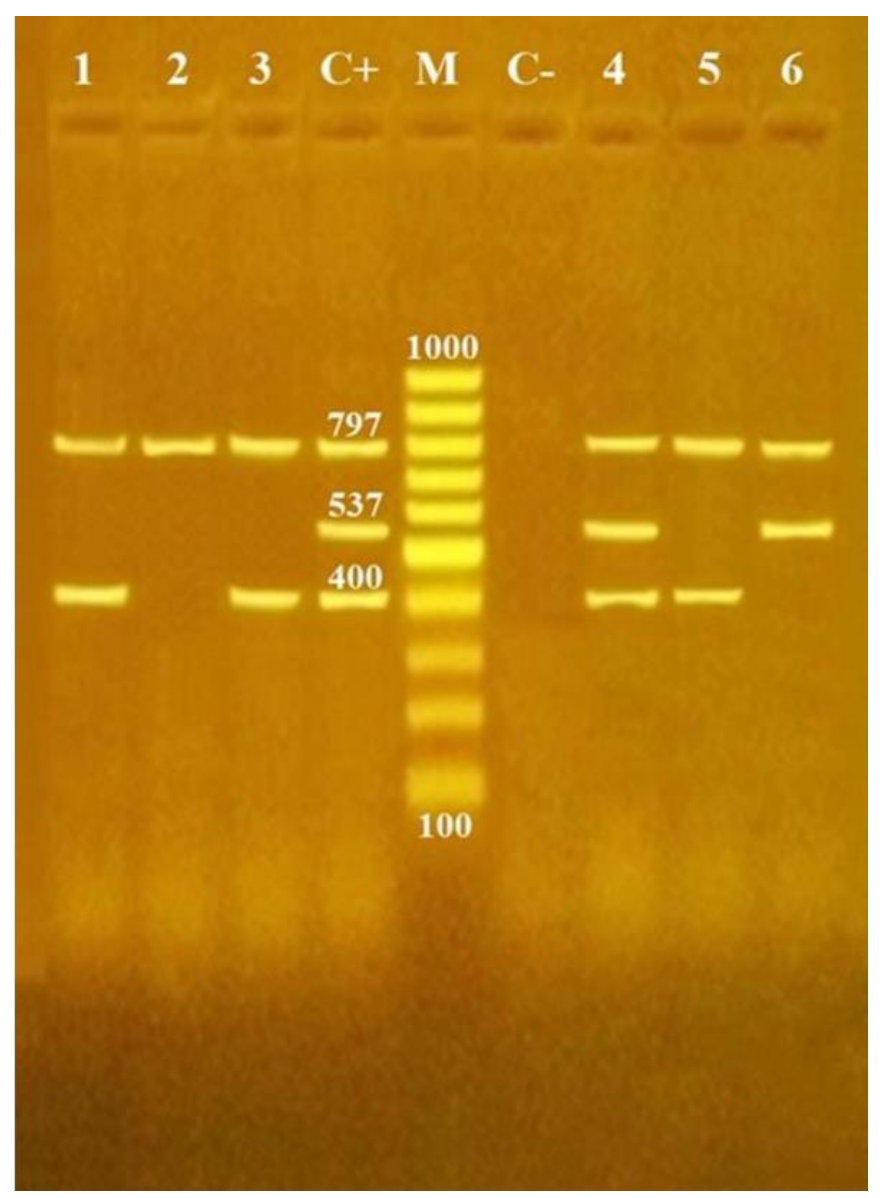

Figure1: Agarose gel electrophoresis of multiplex PCR of nor-1 (400 bp), ver-1 (537 bp) and omtA (797 bp) virulence genes for demonstration of aflatoxigenic strains of Aspergillus flavus

Lane M: 100 bp ladder as molecular size DNA marker

Lane C+: Control positive strain for nor-1, ver-1 and omtA genes

Lane C-: Control negative

Lane 4: Positive A. flavus strain for nor-1, ver-1 and omtA genes

Lanes 1, 3 \& 5: Positive A. flavus strains for nor- 1 and omtA genes

Lanes 6: Positive A. flavus strain for ver-1 and omtA genes

Lane 2: Positive A. flavus strain for omtA gene 


\section{Discussion}

The significance of fish as an imperative wellspring of human protein, particularly in African nations is taken into consideration. The nearness of molds in fish feedstuff is a guide of tainting likely because of an unseemly feed preparing for assembling or insufficient stockpiling of fish feeds motivating the mycotoxin output. Mycotoxins are created by fungal growth causing injurious consequences for human.

In the present study, the isolation rate of fungi from the all 30 fish feedstuffs collected from different fish farms in Kafr El Sheikh governorate involved Aspergillus spp., Penicillium spp., Fusariam spp., Mucor spp. and Rhizopus spp. (86.66\%), (23.33\%), (6.66\%), (10\%), (3.33\%), respectively .This is nearly similar to (35) in Brazil who demonstrated that Aspergillus spp. was the most frequent followed by Penicillium spp. in fish feed intended for fish farms. Similarly, (36) detailed that Aspergillus spp. prevailed alternate types of fungi in fish feedstuffs pursued by Penicillium and Fusarium. Morever, Nunes et al. (37) in Piaui, Brazil declared a higher rate of Penicillium spp. (83.3\%) and Rhizopus spp. (23.3\%) in the fish feed. In between the fungal species, Fusarium spp. was not recovered in fish feed by (35) while was isolated in the examined fish feedstuffs $(10 \%)$. The rate of isolation of Penicillium spp. converted with Embaby et al. (38) who isolated Penicillium spp. in a frequency of (24.4\%). In between Aspergillus species, A .niger was the most predominant nearly agreed with $(35,39)$ who isolated $A$. niger $(36 \%),(40 \%)$ from fish feeds in Brazil and Qena in Egypt, respectively. Marijani et al. (40) isolated A. niger in a lower percentage $(6 \%)$ from fish feed in Kenya, Tanzania, Rwanda and Uganda. Nunes et al. (37) did not isolate $A$. $n i$ ger from the finished fish feed. Many previously investigations reported that the variations in mold species growth and their frequencies might be attributed to different weather conditions in combination with variant storage measures and manufacturing of fish feeds.

Mycotoxins detected by HPLC in the examined samples revealed the incidence of high aflatoxin contamination and low OTA. $\mathrm{AFB}_{1}$ was found in all mycotoxin producing fish feed samples and $\mathrm{AFG}_{2}$ were not found. Nearly similar results were reported by $(37,41)$ as $\mathrm{AFB}_{1}$ in fish feed was (16.7\%) and $(28.5 \%)$ respectively. Also (39) recorded low concentrations of $\mathrm{AFB}_{1}, \mathrm{AFB}_{2}$ and $\mathrm{AFG}_{2}$ differing with this study about $\mathrm{AFG}_{2}$ which not found. The high frequency of $\mathrm{AFB}_{1}$ in fish feed $(55 \%)$ reported by (35) and (40). However, it is substantial to be taken in consider that fish aflatoxicosis has been mentioned in spite of the low concentration of $20 \mathrm{ppb}$ of $\mathrm{AFB}_{1}$ in feed as reported by (44) causing a high risk to consumers through mycotoxins residues in fish musculature fed on aflatoxins especially $\mathrm{AFB}_{1}$ and ochratoxins containing fish feed stuffs. OTA recorded in low rate $(10 \%)$ while (42) revealed that OTA containing samples were $(25 \%)$. This may be attributed to (14) who reported that A. niger is less important OTA producers while Aspergillus ochraceus is considered a big producer of OTA but not found in this investigation while Aspergillus niger was the most frequent.

The aflatoxiginicity of isolated nine A.flavus from the examined fish feedstuffs showed that $66.67 \%$ of A.flavus isolates produced aflatoxins at rate of $50 \%$ above the permissible limit (6 isolates out of 9). This nearly agrees with (43) who reported that $55.5 \%$ of isolated A. flavus (10 isolates out of 18) from fish feed produced aflatoxins. It has been elucidated that a higher rate of aflatoxiginicity of A. flavus in fish feedstuffs produced by (39) that $83 \%$ (10 isolates out of 12) of isolated A.flavus were aflatoxigenic. Accordingly, PCR assay was performed in this study to detect the presence of aflatoxin genes produced by the isolated A. flavus from the examined fish feedstuff using specific primers indicating the aflatoxigenic ability.

\section{Conclusion}

All examined fish feedstuffs intended for fish farms in Kafr El Sheikh governorate showed the presence of fungal growth especially the mycotoxigenic fungi as well the incidence of carcinogenic mycotoxins $\mathrm{AFB}_{1}$, $\mathrm{AFB}_{2}, \mathrm{AFG}_{1}$ and OTA were estimated. HPLC 
and PCR techniques used for mycotoxins detection providing an accurate results. Either improper processing of fish feed ingredients concerning in their manufacturing or inadequate storage are catalyzers for growth of fungi so more adequate measures are required for manufacturing and storage. More reports are needed to provide a new vital insights into $\mathrm{AFB}_{1}$ and OTA levels regarding to fish feeds and their bioaccumulation in fish flesh for human consumption. The relation between protein content of fish feedstuff and the mycotoxin incidence requires more investigations to limit mycotoxin production introduced by fungi.

\section{References}

1. Sharawy ZZ, Thiele R, Abbas EM, El-Magd MA, Hassaan MS, Peter C, Schmidt J, Saborowski R, Goda AMA-S, Slater MJ. Antioxidant response, body composition of whiteleg shrimp litopenaeus vannamei co-cultured with nile tilapia oreochromis niloticus in recirculating aquaculture. Aquaculture Environment Interactions 2017;9:257-268.

2. Enyidi U, Pirhonen J, Kettunen J, Vielma J. Effect of feed protein: lipid ratio on growth parameters of African catfish Clarias gariepinus after fish meal substitution in the diet with bambaranut (Voandzeia Subterranea) meal and soybean (Glycine max) meal. Fishes 2017; 2,1. doi: 10.3390/fishes2010001.

3. Greco MV, Pardo AG, Ludemann V, Martino PE, Pose GN. Mycoflora and natural incidence of selected mycotoxins in rabbit and chinchilla feeds. Sci World J 2012; 1-9.

4. Doerr JA, Campbell JML, Huff W E. Interaction between dietary citrinin and Ochratoxin A in broiler chickens. Poult ScL 1982; 61: 1453.

5. Ariyo LA, Anthony HM, Lami HM. Survey of Mycotoxigenic Fungi in Concentrated Poultry Feed in Niger State, Nigeria. JFR 2013; 2(2)12835.

6. Pestka JJ. Deoxynivalenol toxicity, mechanisms and animal health risks. Anim Feed Sci Technol 2011; 137: 283-98

7. Fuchs R, Appelgren L and Hult K. Distribution of 14C-Ochratoxin A in the rainbow trout Salmogaidneri. Acta Pharmacol. Et Toxicol J P 1986; 220-7.

8. El-Shaboury FA. Fungal flora of Brolus lake fish at Kafr El-Sheikh Province Alex J Vet Sci 1998; 14(3):17-28.
9. Danicke T, Goyarts S, Valenta H, Ueberschar KH. Carry-over of Fusarium toxins (deoxynivalenol and zearalenone) from naturally contaminated wheat to pigs. Food Addit Contam 2011; 25:389-420.

10. Abdelhady D, El-Abasy M, Abou-Asa S, Elbialy Z, Shukry M, Hussein A, Saleh A, El-Magd $M$. The ameliorative effect of aspergillus awamori on aflatoxin b1-induced hepatic damage in rabbits. World Mycotoxin Journal 2017;10:363-73.

11. Stewart D, Larson E. Aflatoxicosis in wildlife. Information Sheet 1582. Mississippi State Univ. Extension Service, Cooperating with U.S. Dept. of Agriculture 2002.

12. D'Mello JPF, MacDonald AMC. Mycotoxins. Anim Feed Sci Technol 1997; 69: 155-66.

13. Santacroce M P, Narracci M, Acquaviva M I, Cavallo R A, Zacchino V, Centoducati G. New Development in Aflatoxin Research: From Aquafeed to Marine Cells, Aflatoxins - Detection, Measurement and Control, Dr Irineo Torres-Pacheco (Ed), ISBN 2011; 978-953-307-711-6.

14. Benford D, Boyle C, Dekant W, Fuchs E, Gaylor D W , Hard G et al. Ochratoxin A Safety Evaluation of Certain Mycotoxins in Food. WHO Food Additives Series 47. FAO Food and Nutrition Paper, WHO, Geneva, Switzerland, 2001; 74: 281415.

15. Samson RA, Stalk A, Hadlok R. Revision on the subsection fasiculata of Penicillium and some allied species. Studies in Mycology 1976; 2: 75-.

16. Mushtaq M, Sultana B, Anwar F, Khan M, Ashrafuzzaman M. Occurrence of aflatoxins in selected processed foods from Pakistan. Int J Mol Sci 2012; 13(7): 8324-37.

17. Cruickshank R, Maimon D, Swain RHA. Medical microbiology $12^{\text {th }}$ ED Vol II Churchil Livingstone, 1975.

18. Raper KB, Fennel DI. The genus Aspergillus. $1^{\text {st }}$ Ed. Williams and Wilkins Company, Baltimore, 1965.

19. Dalcero A, Magnolt C, Luna M, Ancast G, Reynoso MM, Chiacchiera S, Miazzo R, Palacio G. Mycoflora and naturally occurring mycotoxins in poultry feeds in Argentina. Mycopathologia 1998;141 (1): 37-43.

20. Samson RAA. Complication of Aspergilli. Studies in Mycology 1979; 3: 198-202.

21. ARX JA, Pilzkunde J, Cramer inder A R Canter Verlag, Kommanditge sellschaft. FL - 9490 Vaduz 1967.

22. Raper KB, Thom CA. Manual of the penicillia, Williams and Wilkins Company, Baltimore, 1969. 
23. Samson RA, Stalk A, Hadlok R. Revision on the subsection fasiculata of Penicillium and some allied species. Studies in Mycology 1976; 2: 75-8.

24. Zycha H, Siepman R, Linnemann G. Mucorales Eine Besebreibung alter Gattunger und Arten diesser pilzgruppe ver lag Von. J Carmer 1969.

25. Association of Official Analytical Chemists "AOAC" Official Methods of the AOAC International Analysis. 13 ${ }^{\text {th }}$ Ed, Horwitz W, (Editor), Academic Press, Washington D.C, USA, 2000.

26. Toscani T, Moseriti A, Dossena A, Dallasta C, Semoncini N, Virgili R. Determination of ochratoxin $\mathrm{A}$ in dry-cured meat products. J Chromatogr B Analyt Technol Biomed Life Sci 2007; 855(2):242-8.

27. European Council "EC" Commission Regulation No. 401/2006 of 23 February 2006 laying down the methods of sampling and analysis for the official control of the levels of mycotoxins in foodstuffs. Official Journal of the European Union, L70 pp 2006;12-34.

28. Hera S, Fennel D, Hesseltine C. Aflatoxin producing strains of $A$. flavus detected by fluorescence of agar medium under U/V light. Appl Microbiol 1994;47 (6): 118-23.

29. Pestka J. Fungal toxins in raw and fermented meats. Fermented meat, A textbook, (Eds. G Campbell and P E Cook), Blakie Academic and Professional Press, London, UK 1995.

30. Schuller PL, Van Egmond HP, Leonard Stoloff. Limits and regulation on mycotoxins. Proc Int Symp Mycotoxins PP 1983;111-29.

31. Criseo G, Bagnara A, Bisignano G. Differentiation of aflatoxin-producing and non-producing strain of Aspergillus flavus group. Lett Appl Microbiol 2001; 33(4):291-5.

32. Erami M, Hashemi S, Pourbakhsh S, Shahsavandi S, Mohammadi S, Shooshtari A, Jahanshiri Z. Application of PCR on detection of aflatoxinogenic fungi. ARI 2007; 62 (2): 95-100.

33. Davari E, Mohsenzadeh M , Mohammadi G, Shahsavandi S, Doloei R. Characterization of aflatoxigenic Aspergillus flavus and A. parasiticus strain isolates from animal feedstuffs in Northeastern Iran. Iran J Vet Res 2015; 16(2): 150-5.

34. Randhir S, Pradhan K. Forage evaluation. First Published, Printox, New Dalhi, Dhawan Printing works 1981.
35. Barbosa TS, Pereyra CM, Soleiro C, Dias EO, Oliveira A, Keller KM, Silva PP, Cavaglieri LR, Rosa CA. Mycobiota and mycotoxins present in finished fish feeds from farms in the Rio de Janeiro State, Brazil. Int Aquat Res 2013; 5: 3.

36. Cardoso F, F D C. Monitoramento de fungos toxigenicos e aflatoxinas em raçoes utilizadas na piscicultura em Teresina, Piaú, Brasil. Master's Thesis, Universidade Federal do Piauí, Teresina, Brasil. 2011; In Portuguese.

37. Nunes EMCG, Maria M, Gomes-Pereira, Amilton P Raposo-Costa et al. Screening of aflatoxin $\mathrm{B} 1$ and mycobiota related to raw materials and finished feed destined for fish. Lat Am J Aquat Res 2015;43(3): 595-600.

38. Embaby EM , Ayaat NM., Abd El-Galil MM , Allah Abdel-Hameid N, Gouda MM . Mycoflora and mycotoxin contaminated chicken and fish feeds. Mid East J Appl Sci 2015; 5(4):1044-54.

39. Mohamed HMA, Emiesh WFA, Braeuning A, Hammad S. Detection of aflatoxin -producing fungi isolated from Nile Tilapia and fish feed. EXCLI J 2017;16:1308-18.

40. Marijani E, Wainaina James M, Charo-Karisa $\mathrm{H}$, Nzayisenga L, Munguti J, Gnonlonfin BJG, Kigadye M, Okoth S. Mycoflora and mycotoxins in finished fish feed and feed ingredients from smallholder farms in East Africa. Egy J Aquat Res 2017; 43 (2): 169-76.

41. Hashimoto EH, Santos MA, Ono EYS, Hayashi C, Bracarense APFRL, Hirooka EY. Bromatologia e contaminação com fumonisina e aflatoxina em rações utilizadas na piscicultura da região de Londrina, Estado do Paraná, Brasil. Seminario: Ciências Agrárias 2003; 24(1):123-32.

42. Greco M, Pardo A, Pose G. Mycotoxigenic fungi and natural co-occurrence of mycotoxins in rainbow trout (Oncorhynchus mykiss) feeds. Toxins (Basel) 2015; 7(11):4595-609.

43. Hassan AA, Hassan AM, ElShafei MH, El Ahl RMH, Abd El-Dayem RH. Detection of aflatoxigenic moulds isolated from fish and their products and its public health significance. Mater Sci 2011; 9 (9): 106-14.

44. Mahfouz EM, Sherif HA. A Multiparameter investigation into adverse effects of aflatoxin on Oreochromis niloticus health status. J Basic Appl Zool 2015; 71:48-59. 